\title{
PROFITABILITY OF FOOD INDUSTRY COMPANIES IN THE REPUBLIC OF SERBIA
}

\author{
Violeta Domanović ${ }^{1}$, Milica Vujičić ${ }^{2}$, Lela Ristić ${ }^{3}$
}

\begin{abstract}
Summary
Food industry is an important segment of manufacturing industry. The EU food industry is the world's leader. An important characteristic of the food sector of the Republic of Serbia is its pronounced dual structure, with a large number of small and mediumsized and a small number of large companies. It is believed that the relatively modest funds for investment in modern technology and increasing production efficiency, despite foreign direct investment, have an unfavourable effect on the perspective of this sector. Based on the number of companies, capacities, volume of production, export potential, and number of employees, confectionery industry is assessed as a significant segment of food industry and economy of the Republic of Serbia. The research objective is to examine whether reputable companies in the food industry of the Republic of Serbia are profitable and assess their profitability growth in the past four-year period. The research results show that the values of the relevant profitability indicators vary considerably in the observed period, regardless of their reputation and the competitive position on the market.
\end{abstract}

Key words: food industry, confectionery industry, profitability.

JEL: $014, P 27, D 57$.

\section{Introduction}

Food industry is an important segment of manufacturing industry. Food production includes (SORS, 2017): production of biscuits, cookies, preserved pastry goods and cakes, production of cocoa, chocolate, and confectionery products, processing and

1 Violeta Domanović, PhD, Associate professor, University of Kragujevac - Faculty of Economics, Djure Pucara Starog №3, 34000 Kragujevac, Republic of Serbia, Phone: +381 0603851 710, E-mail: vterzic@kg.ac.rs

2 Milica Vujičić, PhD, Full Professor, State University of Novi Pazar - Department of Economic Sciences, Vuka Karadzica bb, 36300 Novi Pazar, Republic of Serbia, Phone: +38106386649 68, E-mail: vujicicmilica@yahoo.com

3 Lela Ristić, PhD, Associate professor, University of Kragujevac - Faculty of Economics, Djure Pucara Starog №3, 34000 Kragujevac, Republic of Serbia, Phone: +381 0603348 719, E-mail: $\underline{\text { ristic@ } @ \text { kg.ac.rs }}$

EP 2018 (65) 1 (11-32) 
preserving meat, fruit, and vegetables, production of oil and fat, milk processing, production of mill products, bread, pastry and cakes, sugar production, tea and coffee processing, spice production and other food products. When it comes to confectionery industry products, they are known to be very diverse (Dalton, 2015; Gavrilović, 2011).

The EU food industry is the largest among the representative countries, judging by turnover, companies, and employment. More precisely, there are three leading regions in food production: the EU - about $44 \%$ of turnover, the USA - about $20 \%$, China - about $19 \%$. Nevertheless, the European Commission is working to improve the competitiveness of the food industry in the European Union. This also implies the creation of new trade opportunities for food and beverages in the European Union (EC, 2017).

The share of food industry in the structure of GVA of the Republic of Serbia is about $4 \%$. The share of food products, beverages, and tobacco in the manufacturing industry GVA is over $30 \%$. The share of food industry in the total number of employees in the manufacturing sector is about $17 \%$, and in the manufacturing industry investment about $16 \%$. The utilization rate of existing food industry capacity is below $65 \%$, which also indicates low efficiency. An important characteristic of the food sector is its dual structure, with a large number of small and medium-sized companies and a small number of large companies. The relatively modest funds for investment in modern technology and increasing production efficiency have an unfavourable impact on the perspective of many existing food companies. In some cases, foreign direct investment has initiated certain shifts. However, technical and technological equipment still varies across subsectors, with larger companies being in a better position. This primarily refers to the milling and bakery industry, sugar producers, confectionery industry, and dairies. Confectionery industry, according to the number of companies, capacities, volume of production, export potential, and number of employees, constitutes a significant part of the food industry of the Republic of Serbia. Bearing in mind that this industry is expanding the production program, introducing new lines, and raising new factories, the capacities are constantly increasing (SPRR, 2014). Serbian Industry Development Strategy and Policy states that the sector of food products, beverages, and tobacco is very important for the future economic activity of the whole country, and an important export sector for all areas, agriculture, trade, catering, etc.

In addition to a large number of foreign and domestic authors who explore factors that directly or indirectly affect the financial performance and its improvement in food industry, i.e. confectionery industry, for further practical improvement in this area in the Republic of Serbia, examples of good practice are of special importance, which especially refers to domestic companies with a long tradition and exceptional quality in the production of food products, such as Soko Štark, Bambi-Požarevac, Swisslion, earlier Takovo-Gornji Milanovac, and others. Hence, the research subject in this paper is profitability of food industry companies in the Republic of Serbia. The research objective is to determine whether food industry, i.e. confectionery industry in the Republic of Serbia, is in the growth phase, expressed by profitability dynamics 
of companies in the previous four-year period, i.e. from 2013 to 2016. The starting hypothesis is that reputable companies in confectionery industry in the Republic of Serbia recorded profitability growth in the observed period.

The work is structured in several parts. The first part gives a theoretical background on the assessment of food industry in the European Union, the USA, post-socialist countries, and the Republic of Serbia. The second part describes the research method, followed by research results and discussion. Finally, conclusion follows, with specified limitations and future research directions.

\section{Theoretical background}

Manufacturing industry is at a maturity phase, going through a turbulent period, due to the growing global requirements regarding food safety, quantity, and the like (EntrenaDurán, 2015). In addition, confectionery industry faces many challenges. The global market for confectionery products is experiencing moderate growth. The growth of this market is expected to accelerate over the period 2016-2021. Chocolate is the most dominant product of the global confectionery market, with around $55 \%$ of the total market value. Sugar confectionery products account for $31.9 \%$ of the confectionery market. Europe occupies $38.4 \%$ of global market of confectionery products, Asia-Pacific $24.2 \%$, USA $23.6 \%$, Middle East $1.9 \%$, and the rest of the world $11.8 \%$. Mondelez International, Inc. is the leader on the global confectionery market, with $14.2 \%$ of market share, followed by Mars, Incorporated with $14 \%$, Nestlé S.A. with $8.7 \%$, The Hershey Company with 5.9\%, and others with 57.3\% (Market Line, 2017b). The European confectionery market is also experiencing moderate growth and is expected to accelerate its development. Germany occupies $17.7 \%$ of the European market of confectionery products, the United Kingdom $14.5 \%$, France $11.3 \%$, Italy $9.0 \%$, Spain $4.9 \%$, and the rest of Europe $42.6 \%$ (Market Line, 2017a). The European Union's food industry is generally competitive on the global stage and produces healthy and safe high-quality food.

Bearing in mind the importance of food industry, i.e. confectionery industry, both globally and at the level of Europe, i.e. the EU and the Republic of Serbia, there are numerous studies in this area, especially when it comes to financial performance and its improvement. Baker (2003) studies several manufacturing industry entities in order to examine the relationship between financial strategic planning and financial performance. $\mathrm{He}$ analyzes different companies in the manufacturing sector: pastry, confectionery, dairy products, jams, jellies and spreads, preserved and frozen vegetables. The most frequently used indicators, such as return on assets (ROA), return on equity (ROE), and return on sales (ROS) are taken as indicators of financial performance. The research results have shown that formal strategic planning is a tool that can be used to increase financial performance of a wide range of food products. This is in line with most studies confirming positive correlation between strategic planning and performance. Grigg \& Walls (2007) study the development of statistical thinking to improve food industry performance. The authors find that statistical quality control methods (SQC) are of 
great importance for this industry. Lyons \& Ma'aram (2014) examine the multiple supply chain strategy in food industry. They point out that thorough understanding of supply chain management (SCM) is crucial to achieving and maintaining competitive advantage. They conclude that, in order to achieve the best possible performance, it is necessary to establish a strong link between supply chain strategy, business strategy, and market requirements. Saitone \& Sexton (2017) study concentration and consolidation in the food supply chain, with particular reference to implications for consumers, farmers, and policy makers in the United States. The authors point out that modern global food system faces the challenges of feeding the population, with an increasing number of food products expected in many highly concentrated industries. In addition, the food system is characterized by growing vertical coordination between different phases and participants. The authors evaluate food sector performance from the standpoint of contemporary challenges and discuss implications of various food industry policy proposals. Their focus is on sectors downstream from the farm, i.e. food processing, distribution, and retailing. Pervan \& Mlikota (2013) discuss what determines the profitability of companies, highlighting the case of food and beverage industry in Croatia. The authors emphasize that food and beverage industry is an important segment of any economy. In addition, they explain that company profitability is always in the interest of both academics and business people, especially with the aim of discovering the main factors that affect the business success of the company. The authors also introduce and test a profitability model that includes structural factors and factors specific to a particular company. Szymanski, Gorton \& Hubbard (2007) perform a comparative analysis of company performance in post-socialist countries, specifically in the food industry in Poland. They compare the performance of companies with different equity structure, taking return on total assets (ROTA) as the performance indicator. The results show that the type of ownership is a significant determinant of company profitability. The Polish experience can be very instructive for other postsocialist countries. Dalton (2015) analyzes the perception of confectionery consumers on the market of the Republic of Serbia, based on a case study. Given a large number of domestic and foreign confectionery products on the market of the Republic of Serbia, the author emphasizes that it is important to evaluate the position of significant products and to formulate the appropriate strategy for the future development of this area.

\section{Research method}

In order to test the starting hypothesis, a case study of food industry companies is applied - Soko Štark d.o.o. Belgrade, Bambi a.d. Požarevac, and Swisslion d.o.o. Belgrade. The profitability of companies in the period 2013-2016 is analyzed.

Soko Štark is part of Atlantic Group, a multinational company that combines production, development, sale, and distribution of consumer goods in its business, with presence on the markets of more than 30 countries around the world. This synergy within a large business system has enabled the opening of new markets, stronger distribution, better positioning and placement - which is the basis for further development of Stark 
and Atlantic Group as a whole. Investing in well-known brands, some of which have significant potential, contributes to the creation of value added and ambitious business plans. Continuous technological advancement and marketing activities serve the purpose of constant innovation, monitoring, and application of modern trends in the field of technology and relations with the market and consumers. As a result of tracking global trends and continuous investment in quality and development, new products are emerging. In 1966, following the integration of the Soko Bakery and the Chocolate and Candy Factory Nada Štark, a Factory of Biscuits, chocolates, and Candies SokoNada Štark emerged, the forerunner of today's modern factory. In 2001, ownership transformation gave rise to a joint-stock company for the production of confectionery products Soko-Nada Štark, Belgrade, with the abbreviated name AD Štark. In 2005, by public takeover, Grand Kafa, the leading coffee manufacturer and distributor in the region, became the majority owner of AD Štark (with around 94\%). By merging Grand Kafa and Droga Kolinska, as the finale of the agreement on strategic integration of these companies, Soko Štark became a member of Droga Kolinska Group. Within this Group, Soko Stark operates as a Business Unit Sweet and Salty. The essence of this organization is division into product programs, sales areas, and local administrations, with the tendency of developing key brands. By acquisition of Droga Kolinska, in 2010, Soko Štark became part of Atlantic Group (Soko Štark d.o.o. Belgrade, 2017).

Bambi a.d. Požarevac started as a children's biscuit factory with only 37 employees and annual production of 167 tons per year in 1967. Bambi is the leader on the domestic confectionery market, with significant regional market share, and one of the 30 most successful companies in the Republic of Serbia. A large number of consumers evaluate Bambi products as the best-quality products. Corporate social responsibility is an integral part of Bambi's identity and business culture, and Bambi is among the leaders in the Republic of Serbia in this field. Bambi a.d. Požarevac strives to be the leading confectionery industry in the Western Balkans region. In 1997, Bambi became the first confectioner in former Yugoslavia to introduce ISO 9001 quality system. In 2000, Bambi was proclaimed the " $20^{\text {th }}$ Century Champion of Quality" at Novi Sad Fair. It was the first and only one in former Yugoslavia to introduce the latest quality management system - ISO 9001:2000. In 2002, Bambi received a HACCP hygiene management certificate, being the first company in Yugoslavia and the first company outside the German speaking area to receive it. In 2004, Bambi received a flattering recognition, "Best Brand of Serbia 2004", for Plazma biscuits, awarded by the Ministry of Trade, Tourism, and Services of the Republic of Serbia and the economic daily Pregled. In 2014, Bambi received an award in the field of corporate social responsibility from the Serbian Chamber of Commerce, as well as the CSR Virtus Award for contribution to the local community. In addition, Plazma was declared the favorite domestic brand in the past decade by the Serbian Chamber of Commerce in the action "Best of Serbia". The BAMBI Group is, therefore, a synonym for lasting value. Knowledge and technology, commitment to customers and consumers, and continuous investment in building strong and recognizable brands are the basics that build confidence and strengthen the 
competitive position. Bambi understands and follows the needs of its customers and always seeks to satisfy their expectations through a diverse range of high-quality and delicious confectionery products (Bambi a.d. Požarevac, 2017).

Swisslion, limited liability company, food industry Belgrade (Savski Venac), was founded on 4 April 2008. The main company activity is the production of chocolate and confectionery products. The story of Swisslion began in 1997. At that time, the first factory was put into operation and SL Technology introduced - a symbol of top-quality natural and healthy food, controlled origin of raw materials, and perfect flavour. From 1997 to 2004, Swisslion launched a total of 11 new production lines, ten in the Republic of Serbia and one in Macedonia. In 2003, the Swisslion factory in Vršac first introduced and implemented a HACCP and hygiene system, based on the recommended international code of practice. It is important to point out that in 2004, in the tender sale of PIK Takovo from Gornji Milanovac, Swisslion entered into the possession of this economic giant. Takovo was integrated into the Swisslion business system, and thus established SwisslionTakovo Group. By integrating Takovo into Swisslion-Takovo Group, Juvitana baby food manufacturing plant became part of it as well. In 2008, the biscuit factory Sisak became part of the company, producing biscuits under Euro Jaffa brand. In April 2011, ice cream factory started operating. In a completely new plant, as Greenfield investment, modern processing equipment was implemented. The whole range of products now relies on a rich assortment of certified confectionery brands. The plant capacity is 30 million liters per year, and it is equipped with automated lines for the production of 54 types of ice cream in all shapes and forms (Swisslion d.o.o. Belgrade, 2017).

In order to analyze the profitability of confectionery industry companies, the most frequently used indicators of company profitability in the period 2013-2016 will be calculated, i.e. return on sales - ROS, return on assets - ROA, and return on equity ROE. Return on sales is obtained as the ratio of net profit and operating revenue. Return on assets is calculated as the ratio between operating profit and average total assets of the company. Return on equity is calculated as the ratio between net profit and average company equity in the observed year. The dynamics of profitability indicators will be monitored using base and chain indices.

Table 1 shows elements of Soko Štark d.o.o. Belgrade profitability in the period 2013-2016.

Table 1. Elements of Soko Štark profitability in the period 2013-2016 in thousands of dinars

\begin{tabular}{|l|l|l|l|l|l|}
\hline Years & $\begin{array}{l}\text { Operating } \\
\text { profit }\end{array}$ & Net profit & $\begin{array}{l}\text { O p e r a t in g } \\
\text { revenue }\end{array}$ & $\begin{array}{l}\text { Average value of } \\
\text { total assets }\end{array}$ & $\begin{array}{l}\text { Average value } \\
\text { of equity }\end{array}$ \\
\hline 2013 & 1032658 & 779743 & 8357904 & 8779396 & 770634,5 \\
\hline 2014 & 595674 & 149024 & 9227271 & 9683478 & 879535,5 \\
\hline 2015 & 964984 & 705983 & 10462098 & 10728435,5 & 1163882 \\
\hline 2016 & 1176002 & 778104 & 10950933 & 11215488,5 & 1859143,5 \\
\hline
\end{tabular}

Source: SBRA, 2017 
Table 2 shows Bambi a.d. Požarevac profitability in the period 2013-2016.

Table 2. Elements of Bambi a.d. Požarevac profitability in the period 2013-2016 in thousands of dinars

\begin{tabular}{|l|l|l|l|l|l|}
\hline Years & $\begin{array}{l}\text { Operating } \\
\text { profit }\end{array}$ & Net profit & $\begin{array}{l}\text { Operating } \\
\text { revenue }\end{array}$ & $\begin{array}{l}\text { Average value of } \\
\text { assets }\end{array}$ & $\begin{array}{l}\text { Average value of } \\
\text { equity }\end{array}$ \\
\hline 2013 & 1869353 & 1718238 & 9113945 & 8284912 & 4673070,5 \\
\hline 2014 & 1937597 & 1725793 & 9244763 & 8927934,5 & 5790414 \\
\hline 2015 & 1695642 & 1336941 & 8716887 & 10352396 & 7470699 \\
\hline 2016 & 2079093 & 1566746 & 9579452 & 11283414,5 & 8617634,5 \\
\hline
\end{tabular}

Source: SBRA, 2017

Table 3 shows Swisslion d.o.o. Belgrade profitability in the period 2013-2016.

Table 3. Elements of Swisslion d.o.o. Belgrade profitability in the period 2013-2016 in thousands of dinars

\begin{tabular}{|l|l|l|l|l|l|}
\hline Years & $\begin{array}{l}\text { Operating } \\
\text { profit }\end{array}$ & Net profit & $\begin{array}{l}\text { Oper a t ing } \\
\text { revenue }\end{array}$ & $\begin{array}{l}\text { Average value of } \\
\text { assets }\end{array}$ & $\begin{array}{l}\text { Average value } \\
\text { of equity }\end{array}$ \\
\hline 2013 & 636203 & 144232 & 9428563 & 9088613,5 & 6964676,5 \\
\hline 2014 & 602077 & 697470 & 8794616 & 9956593 & 7719994 \\
\hline 2015 & 578224 & 494435 & 9612731 & 11272857 & 8271242,5 \\
\hline 2016 & 354319 & 232463 & 9333111 & 11933394,5 & 8647822 \\
\hline
\end{tabular}

Source: SBRA, 2017

\section{Results and discussion}

Table 4 shows Soko Štark d.o.o. Belgrade profitability indicators in the period 2013-2016.

Table 4. Soko Štark profitability indicators in the period 2013-2016

\begin{tabular}{|l|l|l|l|}
\hline Years & Return on sales (ROS) & Return on assets (ROA) & Return on equity (ROE) \\
\hline 2013 & 9,33 & 11,76 & 101,18 \\
\hline 2014 & 1,62 & 6,15 & 16,94 \\
\hline 2015 & 6,75 & 8,99 & 60,66 \\
\hline 2016 & 7,11 & 10,49 & 41,85 \\
\hline
\end{tabular}

Source: Authors, based on SBRA data, 2017

Table 5. Soko Štark d.o.o. Belgrade return on sales dynamics in the period 2013-2016.

\begin{tabular}{|l|l|l|l|}
\hline Years & Return on sales (ROS) & Fixed base indices & Chain indices \\
\hline 2013 & 9,33 & 100 & $/$ \\
\hline 2014 & 1,62 & 17,4 & 17,4 \\
\hline 2015 & 6,75 & 72,3 & 417 \\
\hline 2016 & 7,11 & 76,2 & 105 \\
\hline
\end{tabular}

Source: Authors, based on SBRA data, 2017 
Table 5 and Graph 1 show Soko Stark d.o.o. Belgrade return on sales dynamics in the period 2013-2016.

Graph 1. Soko Štark return on sales dynamics in the period 2013-2016

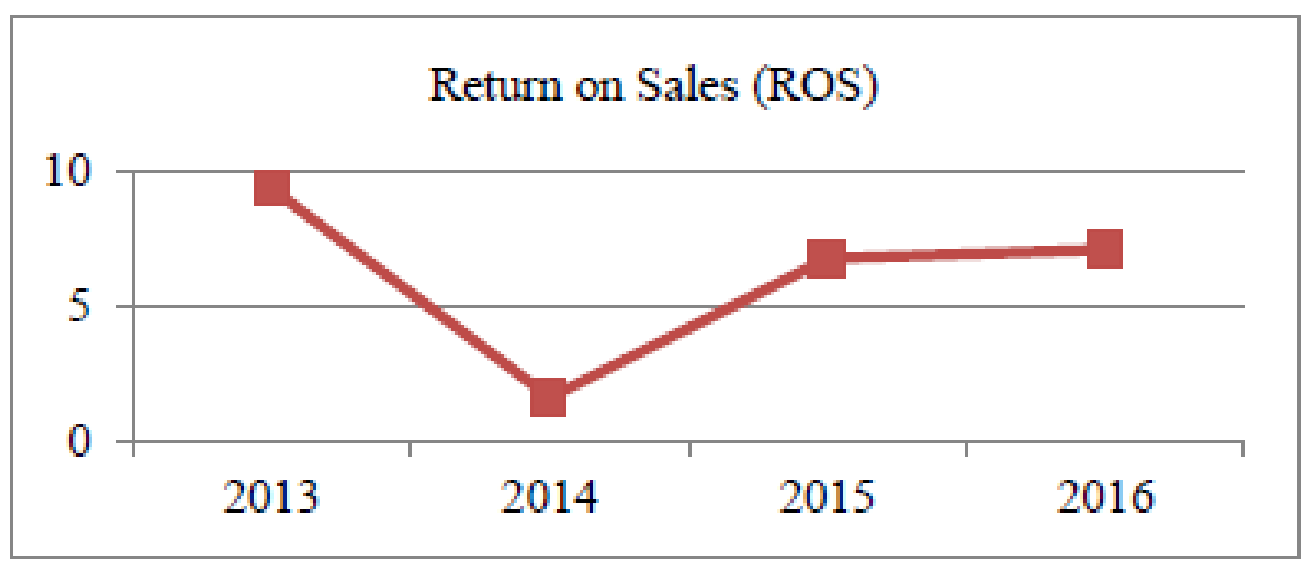

Source: Authors, based on SBRA data, 2017

Comment 1: Table 5 and Graph 1 show that Soko Stark's return on sales (ROS) varies in the observed period. Observed in comparison with 2013, as the base year, return on sales decreased in the observed period, i.e. by $82.6 \%$ in 2014 , by $27.7 \%$ in 2015 , and by $23.8 \%$ in 2016 . Judging by chain indices, return on sales increased by as much as $317 \%$ in 2015, compared to 2014, and only by 5\% in 2016, compared to 2015 .

Table 6 and Graph 2 show Soko Štark d.o.o. Belgrade return on assets (ROA) dynamics in the period 2013-2016.

Table 6. Soko Štark d.o.o. Belgrade return on assets (ROA) dynamics in the period 2013-2016

\begin{tabular}{|l|l|l|l|}
\hline Years & Return on assets (ROA) & Fixed base indices & Chain indices \\
\hline 2013 & 11,76 & 100 & $/$ \\
\hline 2014 & 6,15 & 52,3 & 52,3 \\
\hline 2015 & 8,99 & 7,65 & 146,2 \\
\hline 2016 & 10,49 & 89,2 & 116,7 \\
\hline
\end{tabular}

Source: Authors, based on SBRA data, 2017 
Graph 2. Soko Štark return on assets dynamics (ROA)

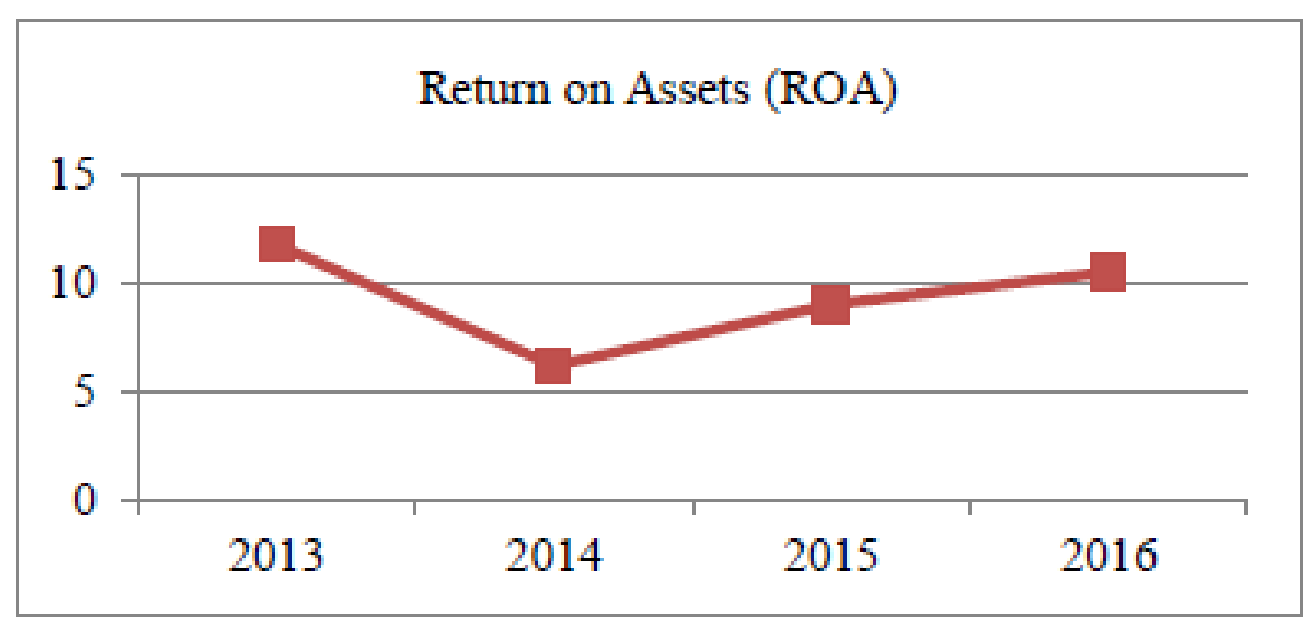

Source: Authors, based on SBRA data, 2017

Comment 2: Table 6 and Graph 2 show, that, compared to 2013, as the base year, return on assets declined by $47.7 \%$ in 2014 , even by $92.35 \%$ in 2015 , and by $10.8 \%$ in 2016 . Judging by chain indices, return on assets increased by $46.2 \%$ in 2015 , compared to the previous year, and by $16.7 \%$ in 2016, compared to 2015 .

Table 7 and Graph 3 show Soko Štark d.o.o. Belgrade return on equity (ROE) dynamics in the period 2013-2016.

Table 7. Soko Štark d.o.o. Belgrade return on equity (ROE) dynamics in the period 2013-2016.

\begin{tabular}{|l|l|l|l|}
\hline Years & Return on equity (ROE) & Fixed base indices & Chain indices \\
\hline 2013 & 101,18 & 100 & $/$ \\
\hline 2014 & 16,94 & 16,74 & 16,74 \\
\hline 2015 & 60,66 & 59,95 & 358 \\
\hline 2016 & 41,85 & 41,36 & 68,99 \\
\hline
\end{tabular}

Source: Authors, based on SBRA data, 2017 
Graph 3. Soko Štark return on equity (ROE) dynamics

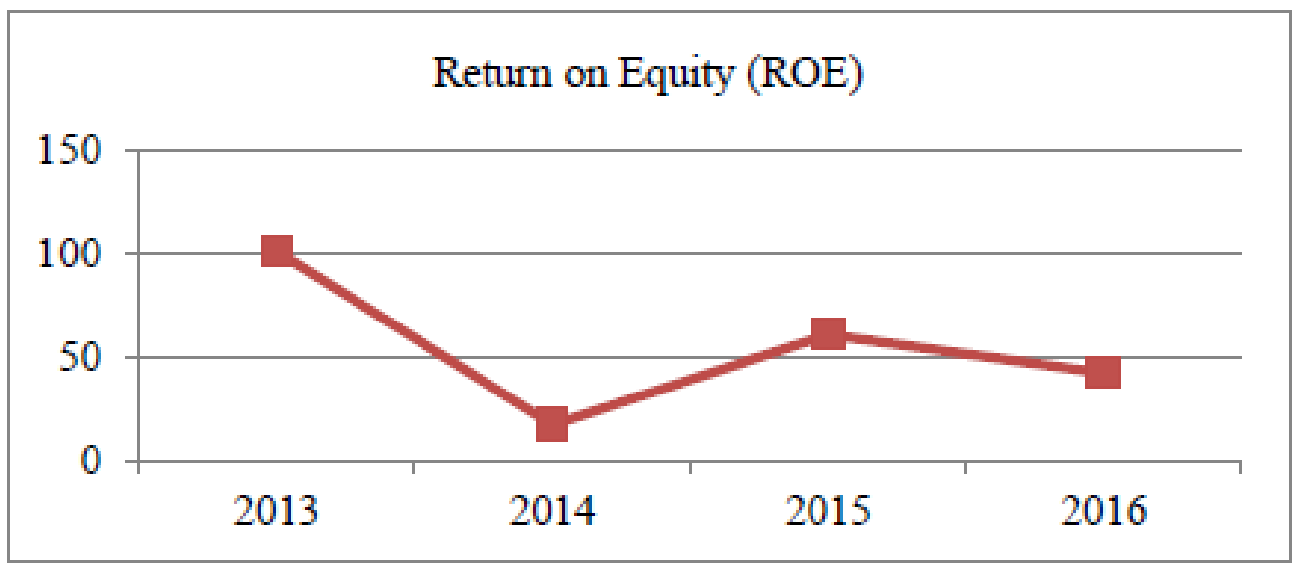

Source: Authors, based on SBRA data, 2017

Comment 3: Table 7 and Graph 3 show that, compared to 2013, as the base year, return on equity declined by $83.26 \%$ in 2014 , by $40.05 \%$ in 2015 , and by $58.64 \%$ in 2016 . Judging by chain indices, return on equity increased by $258 \%$ in 2015 , compared to 2014 , but it declined in 2016 by $31.01 \%$, compared to 2015 .

Table 8 shows Bambi a.d. Požarevac profitability indicators in the period 2013-2016.

Table 8. Bambi a.d. Požarevac profitability indicators in the period 2013-2016

\begin{tabular}{|l|l|l|l|}
\hline Years & $\begin{array}{l}\text { Return on sales } \\
\text { (ROS) }\end{array}$ & $\begin{array}{l}\text { Return on assets } \\
\text { (ROA) }\end{array}$ & $\begin{array}{l}\text { Return on equity } \\
\text { (ROE) }\end{array}$ \\
\hline 2013 & 18,85 & 22,56 & 36,77 \\
\hline 2014 & 18,67 & 21,70 & 29,80 \\
\hline 2015 & 15,34 & 16,38 & 17,9 \\
\hline 2016 & 16,36 & 18,43 & 18,18 \\
\hline
\end{tabular}

Source: Authors, based on SBRA data, 2017

Table 9 and Graph 4 show Bambi a.d. Požarevac return on sales dynamics in the period 2013-2016.

Table 9. Bambi a.d. Požarevac return on sales dynamics in the period 2013-2016

\begin{tabular}{|l|l|l|l|}
\hline Years & Return on sales (ROS) & Fixed base indices & Chain indices \\
\hline 2013 & 18,85 & 100 & $/$ \\
\hline 2014 & 18,67 & 99 & 99 \\
\hline 2015 & 15,34 & 81,4 & 82,2 \\
\hline 2016 & 16,36 & 86,8 & 106,6 \\
\hline
\end{tabular}

Source: Authors, based on SBRA data, 2017 
Graph 4. Bambi a.d. Požarevac return on sales dynamics in the period 2013-2016

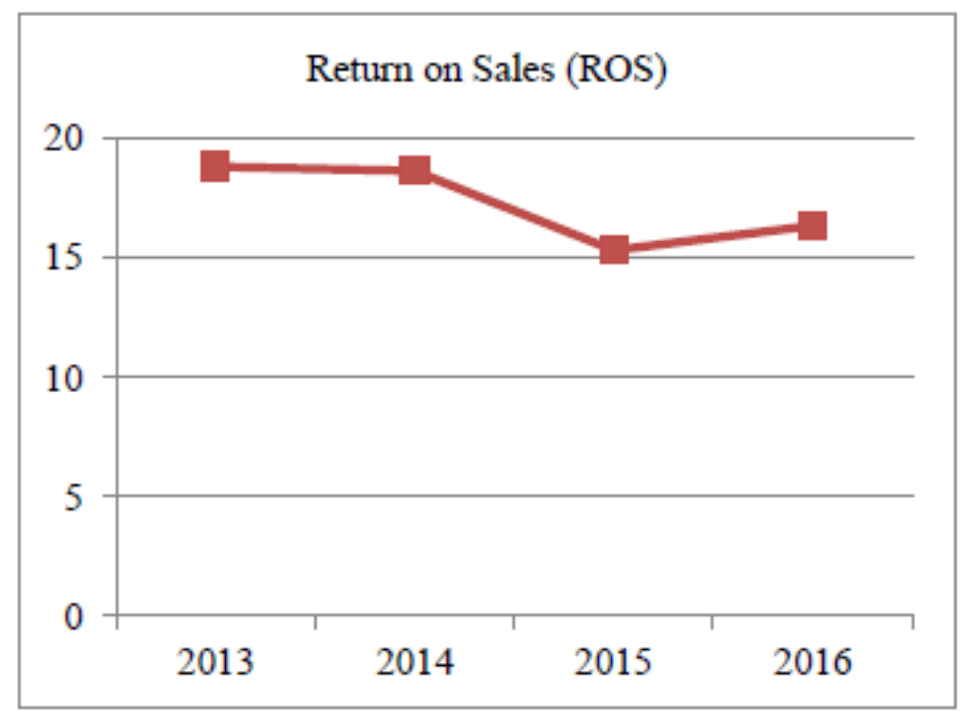

Source: Authors, based on SBRA data, 2017

Comment 4: Table 9 and Graph 4 show that, compared to 2013, as the base year, return on sales fell by only $1 \%$ in 2014 , by $18.6 \%$ in 2015 , and by $13.2 \%$ in 2016 . Judging by chain indices, return on sales fell by $17.8 \%$ in 2015 , compared to 2014 , but slightly increased by $6.6 \%$ in 2016 , compared to 2015 .

Table 10 and Graph 5 show Bambi a.d. Požarevac return on assets dynamics in the period 2013-2016.

Table 10. Bambi a.d. Požarevac return on assets dynamics (ROA) in the period 20132016

\begin{tabular}{|l|l|l|l|}
\hline Years & Return on assets (ROA) & Fixed base indices & Chain indices \\
\hline 2013 & 22,56 & 100 & $/$ \\
\hline 2014 & 21,70 & 96,2 & 96,2 \\
\hline 2015 & 16,38 & 72,6 & 75,5 \\
\hline 2016 & 18,43 & 81,7 & 112,5 \\
\hline
\end{tabular}

Source: Authors, based on SBRA data, 2017 
Graph 5. Bambi a.d. Požarevac return on assets dynamics in the period 2013-2016

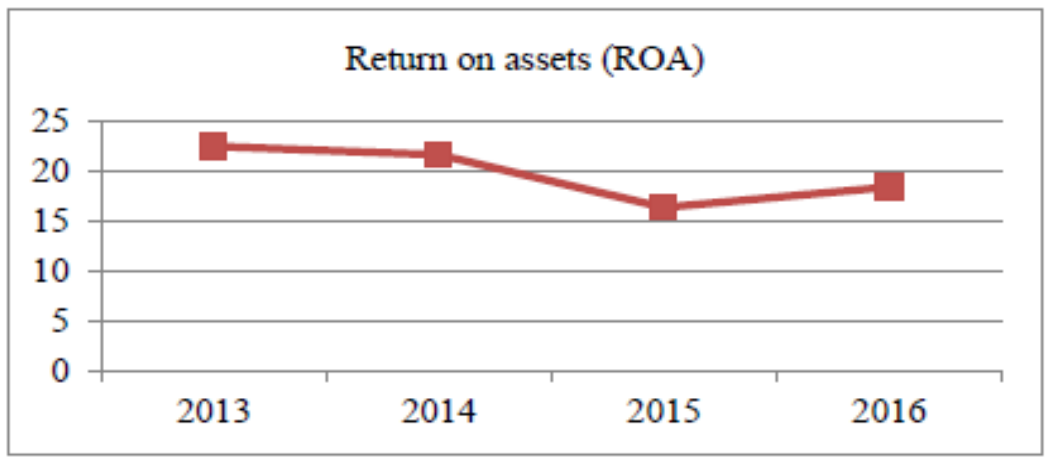

Source: Authors, based on SBRA data, 2017

Comment 5: Table 10 and Graph 5 show that, compared to 2013, as the base year, return on assets decreased in the observed period, by $3.8 \%$ in 2014 , by $27.4 \%$ in 2015 , and by $18.3 \%$ in 2016 . Judging by chain indices, return on assets fell by $24.5 \%$ in 2015 , compared to 2014 , but increased by $12.5 \%$ in 2016 , compared to 2015 .

Table 11 and Graph 6 show Bambi a.d. Požarevac return on equity dynamics in the period 2013-2016.

Table 11. Bambi a.d. Požarevac return on equity (ROE) dynamics in the period 20132016

\begin{tabular}{|l|l|l|l|}
\hline Years & Return on equity (ROE) & Fixed base indices & Chain indices \\
\hline 2013 & 36,77 & 100 & $/$ \\
\hline 2014 & 29,80 & 81,04 & 81,04 \\
\hline 2015 & 17,9 & 48,68 & 60 \\
\hline 2016 & 18,18 & 49,44 & 101,6 \\
\hline
\end{tabular}

Source: Authors, based on SBRA data, 2017

Graph 6. Bambi a.d. Požarevac return on equity dynamics in the period 2013-2016

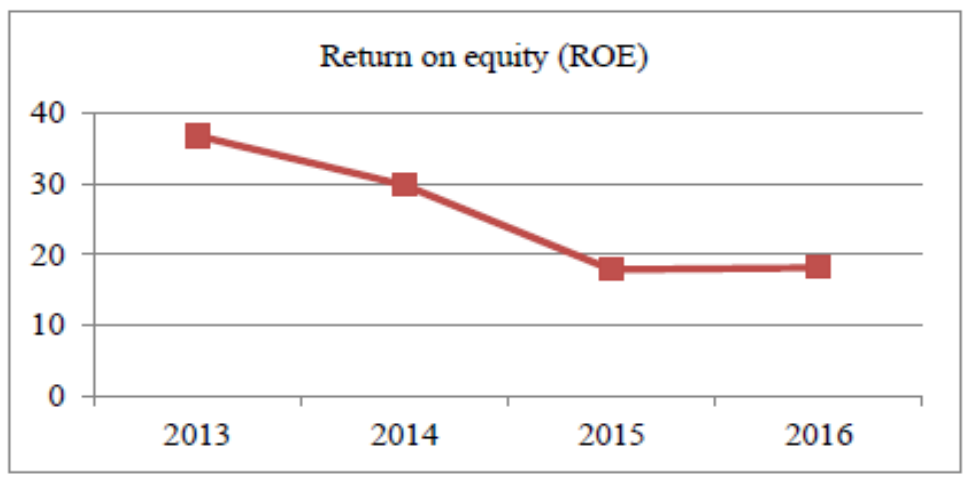

Source: Authors, based on SBRA data, 2017 
Comment 6: Table 11 and Graph 6 show that return on equity decreased, compared to 2013 , as the base year, by $18.96 \%$ in 2014 , by $51.32 \%$ in 2015 , and by $50.56 \%$ in 2016. Judging by chain indices, return on equity declined by as much as $40 \%$ in 2015 , compared to 2014, but slightly increased by $1.6 \%$ in 2016, compared to 2015 .

Table 12 shows Swisslion d.o.o. Belgrade profitability indicators in the period 20132016.

Table 12. Swisslion d.o.o. Belgrade profitability indicators in the period 2013-2016

\begin{tabular}{|l|l|l|l|}
\hline Years & $\begin{array}{l}\text { Return on sales } \\
\text { (ROS) }\end{array}$ & $\begin{array}{l}\text { Return on assets } \\
\text { (ROA) }\end{array}$ & $\begin{array}{l}\text { Return on equity } \\
\text { (ROE) }\end{array}$ \\
\hline 2013 & 1,53 & 7 & 2,07 \\
\hline 2014 & 7,93 & 6,05 & 9,03 \\
\hline 2015 & 5,14 & 5,13 & 5,98 \\
\hline 2016 & 2,49 & 2,97 & 2,69 \\
\hline
\end{tabular}

Source: Authors, based on SBRA data, 2017

Table 13 and Graph 7 show Swisslion d.o.o. Belgrade return on sales dynamics in the period 2013-2016.

Table 13. Swisslion d.o.o. Belgrade return on sales (ROS) dynamics in the period 2013-2016

\begin{tabular}{|l|l|l|l|}
\hline Years & Return on sales (ROS) & Fixed base indices & Chain indices \\
\hline 2013 & 1,53 & 100 & $/$ \\
\hline 2014 & 7,93 & 518 & 518 \\
\hline 2015 & 5,14 & 336 & 64,8 \\
\hline 2016 & 2,49 & 163 & 48,4 \\
\hline
\end{tabular}

Source: Authors, based on SBRA data, 2017

Graph 7. Swisslion d.o.o. Belgrade return on sales dynamics in the period 2013-2016

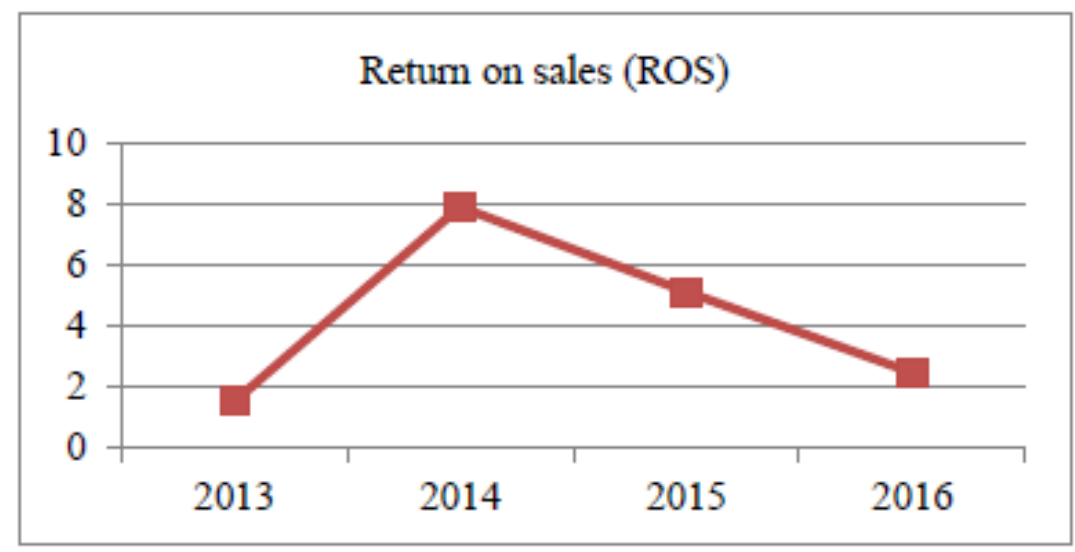

Source: Authors, based on SBRA data, 2017

EP 2018 (65) 1 (11-32) 
Comment 7: Table 13 and Graph 7 show that return on sales of the observed company increased in the observed period, even by $418 \%$ in 2014 , compared to 2013 , by $236 \%$ in 2015 , and by $63 \%$ in 2016 , compared to 2013 . Judging by chain indices, return on sales fell by $35.2 \%$ in 2015, compared to 2014, and by $51.6 \%$ in 2016, compared to 2015 .

Table 14 and Graph 8 show Swisslion d.o.o. Belgrade return on assets dynamics in the period 2013-2016.

Table 14. Swisslion d.o.o. Belgrade return on assets dynamics (ROA) in the period 2013-2016

\begin{tabular}{|l|l|l|l|}
\hline Years & Return on assets (ROA) & Fixed base indices & Chain indices \\
\hline 2013 & 7 & 100 & $/$ \\
\hline 2014 & 6,05 & 86,4 & 86,4 \\
\hline 2015 & 5,13 & 73,3 & 84,8 \\
\hline 2016 & 2,97 & 42,4 & 57,89 \\
\hline
\end{tabular}

Source: Authors, based on SBRA data, 2017

Graph 8. Swisslion d.o.o. Belgrade return on assets dynamics in the period 2013-2016

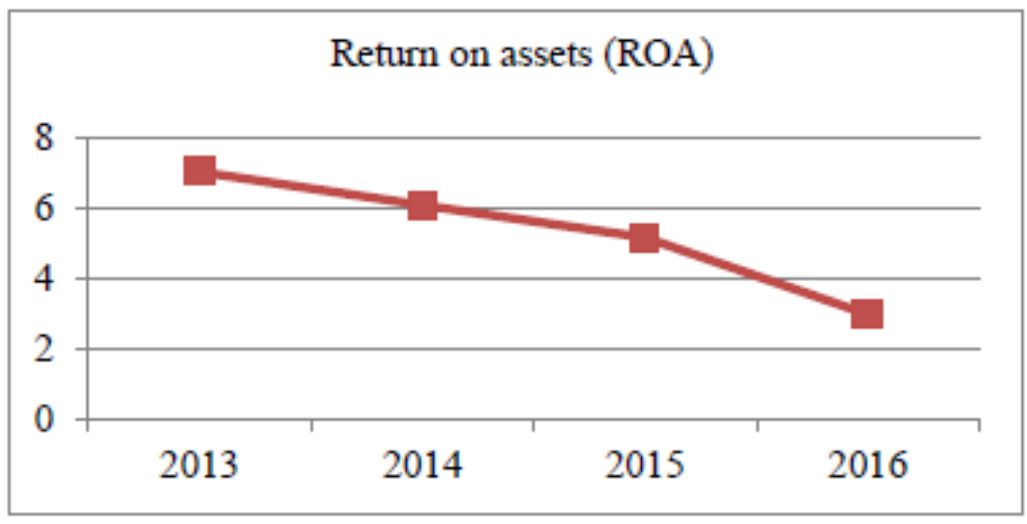

Source: Authors, based on SBRA data, 2017

Comment 8: Table 14 and Graph 8 show that return on assets declined in the observed period. Observed in comparison with 2013, as the base year, return on assets declined by $13.6 \%$ in 2014 , by $26.7 \%$ in 2015 , and by $57.6 \%$ in 2016 . Judging by chain indices, return on assets fell by $15.2 \%$ in 2015 , compared to 2014 , and by $42.11 \%$ in 2016 , compared to 2015.

Table 15 and Graph 9 show Swisslion d.o.o. Belgrade return on equity dynamics in the period 2013-2016. 
Table 15. Swisslion d.o.o. Belgrade return on equity (ROE) dynamics in the period 2013-2016

\begin{tabular}{|l|l|l|l|}
\hline Years & Return on equity (ROE) & Fixed base indices & Chain indices \\
\hline 2013 & 2,07 & 100 & $/$ \\
\hline 2014 & 9,03 & 436,23 & 436,23 \\
\hline 2015 & 5,98 & 289 & 66,22 \\
\hline 2016 & 2,69 & 129,95 & 44,98 \\
\hline
\end{tabular}

Source: Authors, based on SBRA data, 2017

Graph 9. Return on equity dynamics (ROE)

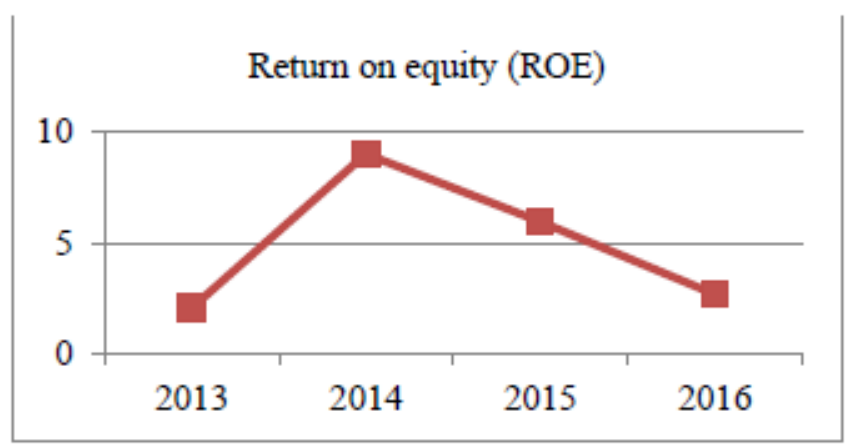

Source: Authors, based on SBRA data, 2017

Comment 9: Table 15 and Graph 9 show that return on equity increased by $336.23 \%$ in 2014 , compared to 2013 , by $189 \%$ in 2015 , and by $29.95 \%$ in 2016 , compared to 2013 , as the base year. Judging by chain indices, return on equity fell by $33.78 \%$ in 2015 , compared to 2014, and by $55.02 \%$ in 2016, compared to 2015.

Table 16 and Graph 10 compare profitability indicators of the observed companies in 2013. It can be concluded that, in the observed year, Bambi a.d. Požarevac had the highest return on sales, while Swisslion d.o.o. Belgrade had the lowest. Bambi a.d. Požarevac had the highest return on assets, and the lowest rate was again recorded in Swisslion d.o.o Belgrade. Soko Štark d.o.o. Belgrade had the highest return on equity, and the lowest rate was again in Swisslion d.o.o. Belgrade.

Table 16. Profitability indicators of observed companies in 2013

\begin{tabular}{|l|l|l|l|}
\hline Companies & ROS & ROA & ROE \\
\hline Soko Štark & 9,33 & 11,76 & 101,18 \\
\hline Bambi & 18,85 & 22,56 & 36,77 \\
\hline Swisslion & 1,53 & 7 & 2,07 \\
\hline
\end{tabular}

Source: Authors, based on SBRA data, 2017 
Graph 10. Profitability dynamics of the observed companies in 2013

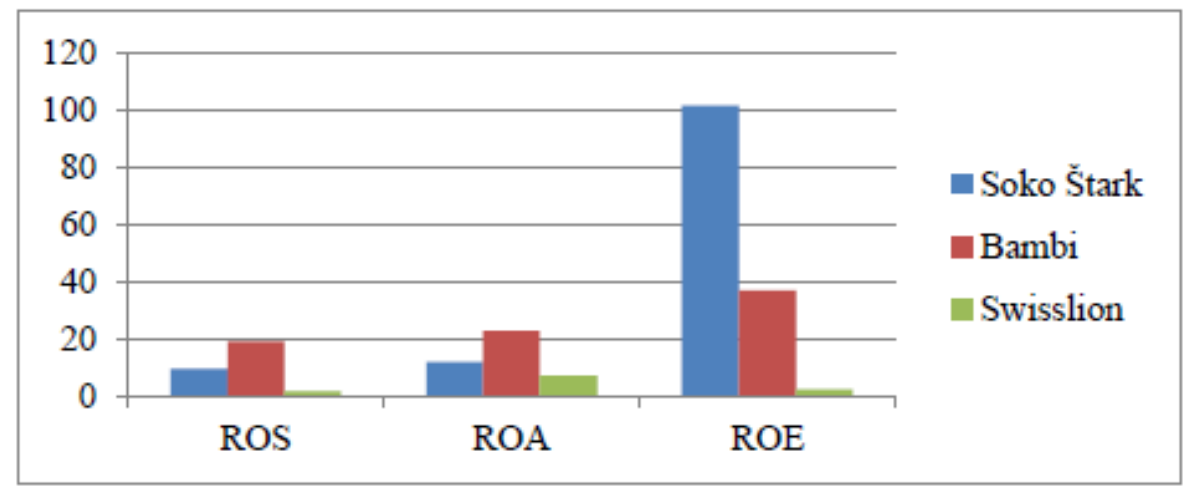

Source: Authors, based on SBRA data, 2017

Table 17 and Graph 11 give a comparative overview of profitability indicators in 2014 . Bambi a.d. Požarevac had the highest return on sales, the highest return on assets, and the highest return on equity. Soko Štark had the lowest return on sales, and Swisslion had the lowest return on assets and return on equity.

Table 17. Profitability indicators of observed companies in 2014

\begin{tabular}{|l|l|l|l|}
\hline Companies & ROS & ROA & ROE \\
\hline Soko Štark & 1,62 & 6,15 & 16,94 \\
\hline Bambi & 18,67 & 21,70 & 29,80 \\
\hline Swisslion & 7,93 & 6,05 & 9,03 \\
\hline
\end{tabular}

Source: Authors, based on SBRA data, 2017

Graph 11. Profitability dynamics of the observed companies in 2014

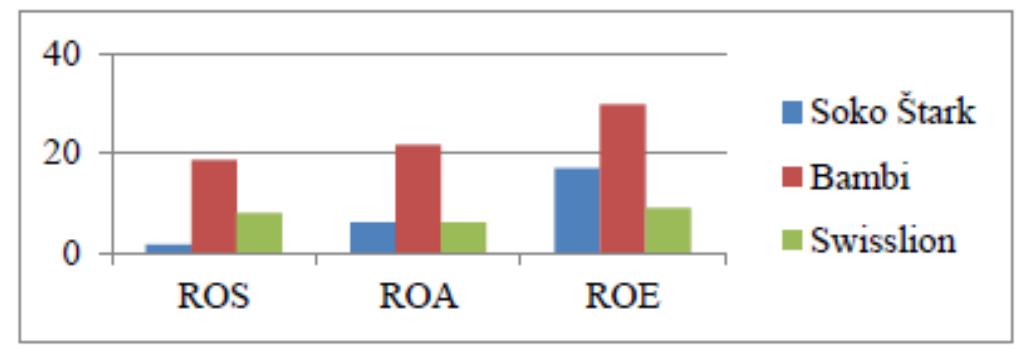

Source: Authors, based on SBRA data, 2017

Table 18 and Graph 12 compare companies' profitability indicators in 2015. Bambi a.d. Požarevac again had the highest return on sales and the highest return on assets, while Swisslion d.o.o. Belgrade again had the lowest return on sales, the lowest return on assets and return on equity. Soko Štark d.o.o. Belgrade had the highest return on equity. 
Table 18. Profitability indicators of observed companies in 2015

\begin{tabular}{|l|l|l|l|}
\hline Companies & ROS & ROA & ROE \\
\hline Soko Štark & 6,75 & 8,99 & 60,66 \\
\hline Bambi & 15,34 & 16,38 & 17,9 \\
\hline Swisslion & 5,14 & 5,13 & 5,98 \\
\hline
\end{tabular}

Source: Authors, based on SBRA data, 2017

Graph 12. Profitability dynamics of observed companies in 2015

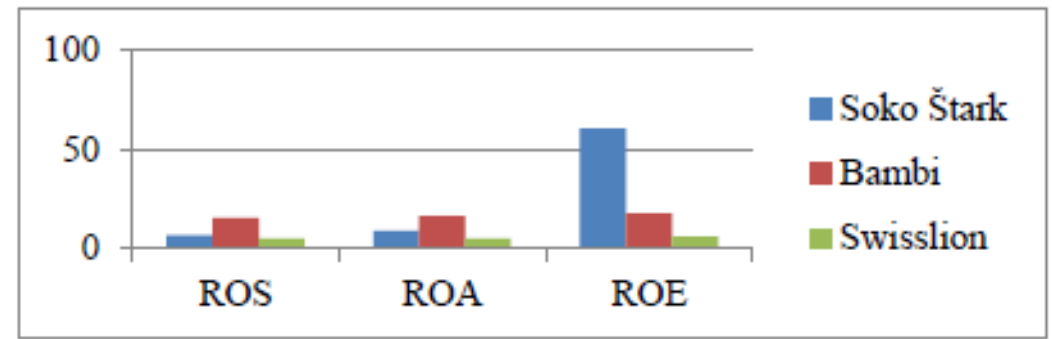

Source: Authors, based on SBRA data, 2017

Table 19 and Graph 13 compare the observed companies' profitability indicators in 2016. Bambi a.d. Požarevac again had the highest return on sales and return on assets. Soko Štark d.o.o. Belgrade has the highest return on equity. Swisslion d.o.o. Belgrade again had the lowest return on assets and return on equity.

Table 19. Profitability indicators of observed companies in 2016

\begin{tabular}{|l|l|l|l|}
\hline Companies & ROS & ROA & ROE \\
\hline Soko Štark & 7,11 & 10,49 & 41,85 \\
\hline Bambi & 16,36 & 18,43 & 18,18 \\
\hline Swisslion & 2,49 & 2,97 & 2,69 \\
\hline
\end{tabular}

Source: Authors, based on SBRA data, 2017

Graph 13. Profitability dynamics of observed companies in 2016

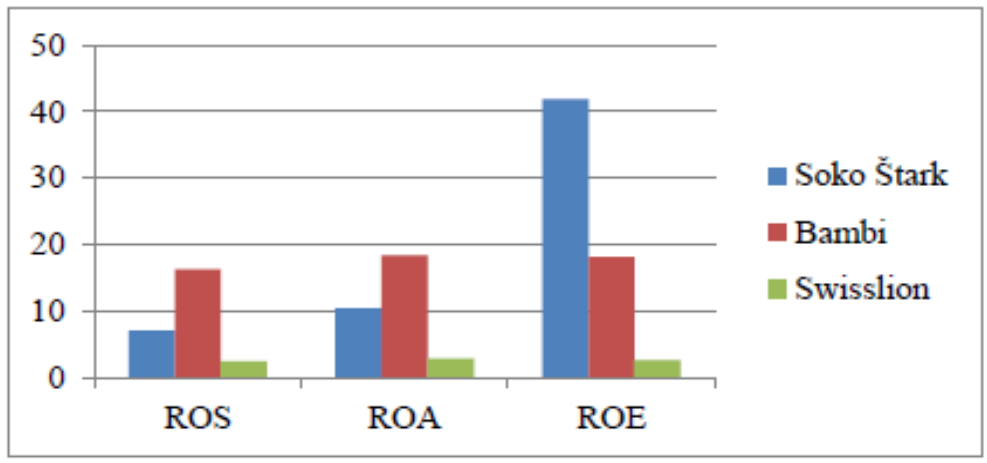

Source: Authors, based on SBRA data, 2017

EP 2018 (65) 1 (11-32) 
Tables 20 - 22 and Graphs $14-16$ show the dynamics of individual company profitability indicators in the period 2013-2016, on the basis of which it is clearer which company is the most profitable, and which is least profitable. In general, it can be concluded that, based on return on sales and return on total assets, Bambi a.d. Požarevac was the most profitable, while Swisslion d.o.o. Belgrade was the least profitable. From the point of view of return on equity, Soko Štark d.o.o. Belgrade was the most profitable company, while Swisslion d.o.o. Belgrade was again the least profitable.

Table 20. Return on sales (ROS) dynamics of observed companies in the period 20132016

\begin{tabular}{|l|l|l|l|}
\hline Years & Soko Štark & Bambi & Swisslion \\
\hline 2013 & 9,33 & 18,85 & 1,53 \\
\hline 2014 & 1,62 & 18,67 & 7,93 \\
\hline 2015 & 6,75 & 15,34 & 5,14 \\
\hline 2016 & 7,11 & 16,36 & 2,49 \\
\hline
\end{tabular}

Source: Authors, based on SBRA data, 2017

Graph 14. Return on sales (ROS) dynamics of observed companies in the period 20132016

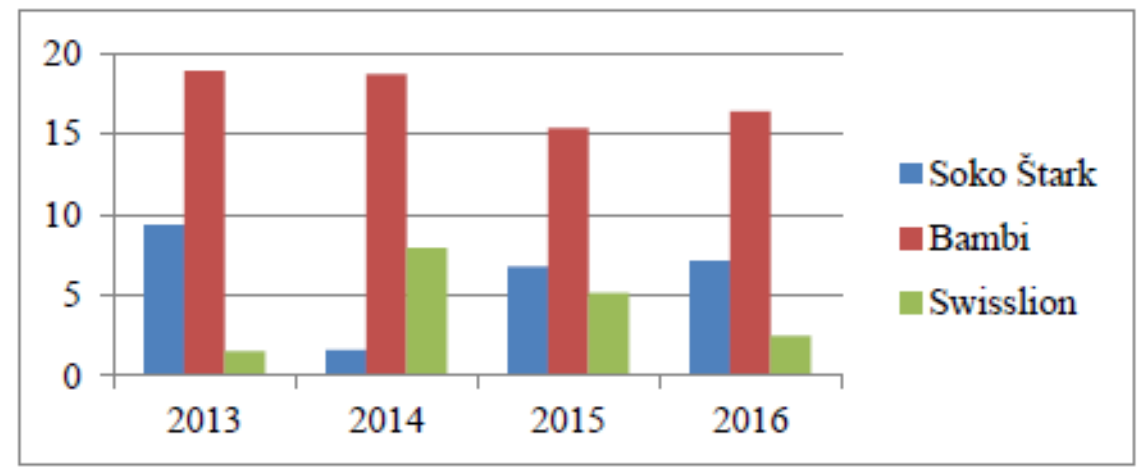

Source: Authors, based on SBRA data, 2017

Table 21. Return on assets (ROA) dynamics of observed companies in the period 20132016

\begin{tabular}{|l|l|l|l|}
\hline Years & Soko Štark & Bambi & Swisslion \\
\hline 2013 & 11,76 & 22,56 & 7 \\
\hline 2014 & 6,15 & 21,70 & 6,05 \\
\hline 2015 & 8,99 & 16,38 & 5,13 \\
\hline 2016 & 10,49 & 18,43 & 2,97 \\
\hline
\end{tabular}

Source: Authors, based on SBRA data, 2017 
Graph 15. Return on assets (ROA) dynamics of observed companies in the period 2013-2016

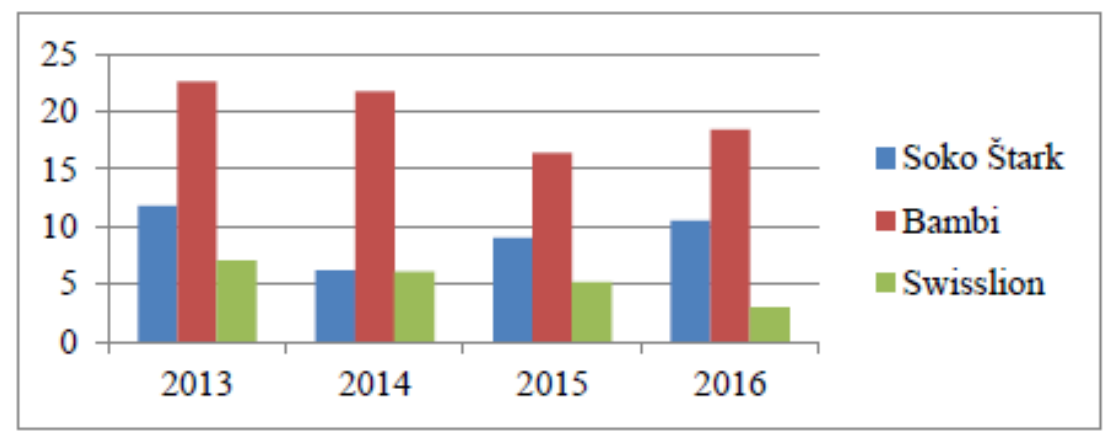

Source: Authors, based on SBRA data, 2017

Table 22. Return on equity (ROE) dynamics of observed companies in the period 2013-2016

\begin{tabular}{|l|l|l|l|}
\hline Years & Soko Stark & Bambi & Swisslion \\
\hline 2013 & 101,18 & 36,77 & 2,07 \\
\hline 2014 & 16,94 & 29,80 & 9,03 \\
\hline 2015 & 60,66 & 17,9 & 5,98 \\
\hline 2016 & 41,85 & 18,18 & 2,69 \\
\hline
\end{tabular}

Source: Authors, based on SBRA data, 2017

Graph 16. Return on equity (ROE) dynamics in the period 2013-2016

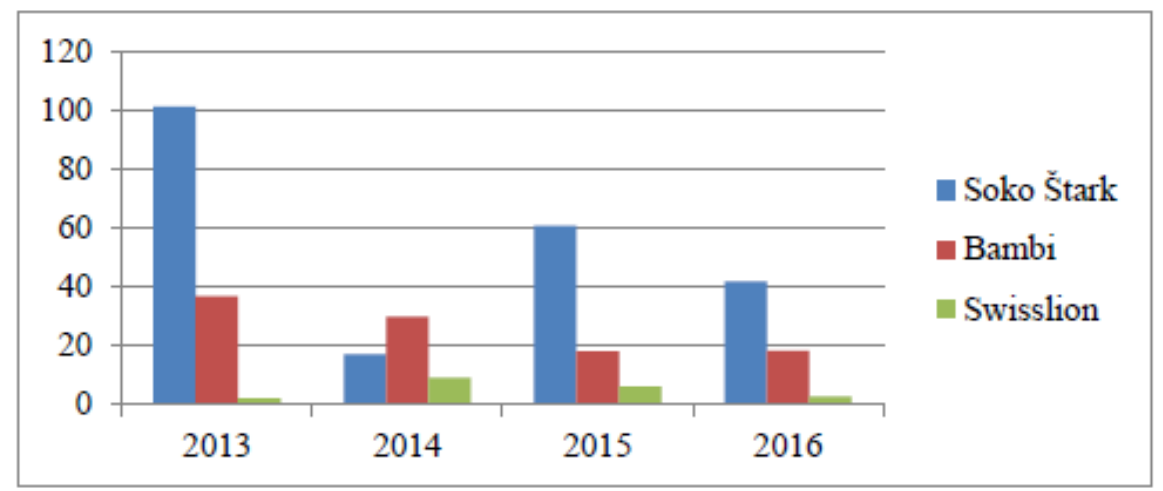

Source: Authors, based on SBRA data, 2017

\section{Conclusion}

Based on the conducted research, it can be concluded that profitability of renowned food industry companies in the Republic of Serbia has significantly varied in the last four-year period.

In Soko Štark d.o.o. Belgrade, return on sales (ROS) declined, compared to 2013, while, judging by chain indices, it increased. Return on assets (ROA) declined in relation to 
2013, and, in terms of chain indices, it increased. Return on equity (ROE) declined in relation to 2013, increased in 2015, compared to 2014, but declined in 2016, compared to 2015 .

In Bambi a.d. Požarevac, return on sales (ROS) also declined, compared to 2013, as the base year. Observed by chain indices, this ratio dropped in 2015, in relation to 2014, and slightly increased in 2016, compared to 2015. Return on assets (ROA) declined, compared to 2013, as the base year. In chain terms, return on assets declined in 2015, compared to 2014, but increased in 2016, relative to 2015. Return on equity (ROE) declined relative to base year, 2013. By chain indices, return on equity declined in 2015, relative to 2014, but slightly increased in 2016, compared to 2015 .

In Swisslion d.o.o. Belgrade, return on sales (ROS) increased in the observed period, compared to the base year, 2013. In chain terms, return on sales declined in 2015, compared to 2014, and in 2016, compared to 2015. Return on assets (ROA) declined in the observed period, both in terms of base and chain indices. Return on equity (ROE) increased in base index terms. Under chain indices, return on equity declined in 2015 , relative to 2014, and in 2016, compared to 2015.

Comparatively, the highest return on sales in 2013 was recorded in Bambi a.d. Požarevac, and the lowest in Swisslion d.o.o. Belgrade. Bambi a.d. Požarevac had the highest return on assets, and the lowest rate was again in Swisslion d.o.o. Belgrade. Soko Štark d.o.o. Belgrade had the highest return on equity, and the lowest rate was in Swisslion d.o.o. Belgrade. In 2014, Bambi had the highest return on sales, the highest return on assets, and the highest return on equity. Soko Stark had the lowest return on sales, while Swisslion had the lowest return on assets and return on equity. In 2015, Bambi a.d. Požarevac again had the highest return on sales and the highest return on assets, while Swisslion d.o.o. Belgrade again had the lowest return on sales, the lowest return on assets and return on equity. Soko Štark d.o.o. Belgrade had the highest return on equity. In 2016, Bambi a.d. Požarevac again had the highest return on sales and return on assets, Soko Štark d.o.o. Belgrade had the highest return on equity, and Swisslion d.o.o. Belgrade again had the lowest return on assets and return on equity.

In general, it can be concluded that, based on return on sales and return on total business assets, the most profitable company was Bambi a.d. Požarevac, while the least profitable was Swisslion d.o.o. Belgrade. From the point of view of return on equity, Soko Stark d.o.o. Belgrade was the most profitable, and the least profitable was Swisslion d.o.o. Belgrade. Bearing in mind the results obtained, it can be concluded that the starting hypothesis cannot be accepted, because food industry companies of the Republic of Serbia did not record profitability growth in the last four-year period. The research limitation is reflected above all in the number of analyzed food industry companies. In the future, the research sample should be increased and consideration should be given to overcoming the unsatisfactory profitability trend of the observed companies. 


\section{Literature}

1. Baker, G. A. (2003). Strategic Planning and Financial Performance in the Food Processing Sector. Review of Agricultural Economics, 25(2), pp. 470-482.

2. Bambi a.d. Požarevac, available at: http://bambi.rs/kompanija/ (09.11.2017.)

3. Dalton, S. (2015). The Analysis of Consumers' Perception of the Confectionary Products in the Serbian Market - Case Study of Chipita Products. Marketing, 46(4), pp. 297-308.

4. EC (2017). Food and drink industry. European Commission, Brussels, Belgium, available at: https://ec.europa.eu/growth/sectors/food_en (09.11.2017.)

5. Entrena-Durán, F. (2015). Food Production and Eating Habits From Around the World: A Multidisciplinary Approach, Nova Science Publishers, Inc., New York.

6. Gavrilović, M. (2011). Tehnologija konditorskih proizvoda, Mlinpek Zavod, Novi Sad.

7. Grigg, N. P. \& Walls, L. (2007). Developing statistical thinking for performance improvement in the food industry. International Journal of Quality \& Reliability Management, 24(4), pp. 347-369.

8. Lyons, A. C. \& Ma'aram, A. (2014). An examination of multi-tier supply chain strategy alignment in the food industry. International Journal of Production Research, 52(7), pp. 1911-1925.

9. Market Line (2017a). Confectionery in Europe, London, United Kingdom.

10. Market Line (2017b). Global Confectionery, London, United Kingdom.

11. Pervan, M. \& Mlikota, M. (2013). What determines the profitability of companies: case of Croatian food and beverage industry. Economic research, 26(1), pp. 277-286.

12. Saitone, T. L. \& Sexton, R. J. (2017). Concentration and Consolidation in the U.S. Food Supply Chain: The Latest Evidence and Implications for Consumers, Farmers and Policymakers. Economic Review, special issue 2017, pp. 25-59.

13. SBRA - Serbian Business Registers Agency (APR - Agencija za privredne registre), Belgrade, available at: http://pretraga2.apr.gov.rs/pretragaObveznikaFI/ (07.11.2017.)

14. Soko Štark d.o.o. Belgrade, available at: http://www.stark.rs/o-nama/ (06.11.2017.)

15. SORS (2017). Nomenclature of industrial products for the annual survey on industry in 2016, Statistical Office of the Republic of Serbia, Belgrade.

16. SPRR (2014). Strategija poljoprivrede i ruralnog razvoja Republike Srbije za period 2014-2024, Vlada Republike Srbije, Beograd.

17. Strategy and policy of industry development in Republic Serbia 2011-2020 (2011). Strategija i politika razvoja industrije Republike Srbije od 2011. do 2020. Vlada Republike Srbije, Beograd.

18. Szymanski, A., Gorton, M. \& Hubbard, L. (2007). A Comparative Analysis of Firm Performance in Post-socialist Economies: Evidence from the Polish Food Processing Industry. Post-Communist Economies, 19(4), pp. 433-449.

19. Swisslion d.o.o. Belgrade, available at: http://www.swisslion-takovo.com/o-nama/ (07.11.2017.) 


\title{
PROFITABILNOST PREDUZEĆA PREHRAMBENE INDUSTRIJE U REPUBLICI SRBIJI
}

\author{
Violeta Domanović ${ }^{4}$, Milica Vujičićr, Lela Ristić ${ }^{6}$
}

\begin{abstract}
Sažetak
Prehrambena industrija je važan segment prerađivačke industrije. Prehrambena industrija EU je vodeća u svetu. Kao važna karakteristika prehrambenog sektora Republike Srbije navodi se izražena dualna struktura, sa mnogo malih i srednjih $i$ manjim brojem velikih privrednih društava. Smatra se da relativno skromna finansijska sredstva za ulaganje u savremenu tehnologiju i povećanje efikasnosti proizvodnje, $i$ pored stranih direktnih investicija, nepovoljno deluju na perspektivu ovog sektora. Konditorska industrija se, prema broju privrednih društava, kapacitetima, obimu proizvodnje, potencijalima za izvoz i broju zaposlenih, ocenjuje kao značajan segment prehrambene industrije i privrede Republike Srbije. Cilj istraživanja je da se ispita da li su renomirana preduzeća u prehrambenoj industriji Republike Srbije profitabilna $i$ da li je reč o rastućoj profitabilnosti ili ne, u poslednjem četvorogodišnjem periodu. Rezultati istraživanja pokazuju da vrednosti relevantnih pokazatelja rentabilnosti značajno variraju u posmatranom periodu naviše $i$ naniže, bez obzira na njihovu reputaciju i konkurentsku poziciju na tržištu.
\end{abstract}

Ključne reči: prehrambena industrija, konditorska industrija, profitabilnost.

4 Vanredni profesor, dr Violeta Domanović, Univerzitet u Kragujevcu - Ekonomski fakultet, Đure Pucara Starog br. 3, 34000 Kragujevac, Republika Srbija, Telefon: 0603851710 , E-mail: vterzic@kg.ac.rs

5 Redovni profesor, dr Milica Vujičić, Državni univerzitet u Novom Pazaru - Departman za ekonomske nauke, Vuka Karadžića bb, 36300 Novi Pazar, Republika Srbija, Telefon: +381 06386649 68, E-mail: vujicicmilica@yahoo.com

6 Vanredni profesor, dr Lela Ristić, Univerzitet u Kragujevcu - Ekonomski fakultet, Đure Pucara Starog br. 3, 34000 Kragujevac, Republika Srbija, Telefon: 0603348 719, E-mail: lristic@,kg.ac.rs 